\title{
PENGARUH AKTIFITAS FISIK MAKSIMAL TERHADAP JUMLAH LEUKOSIT DAN HITUNG JENIS LEUKOSIT PADA ATLET SOFTBALL
}

\author{
Oleh \\ Deni Rahman Marpaung1, Fajar Apollo Sinaga ${ }^{1}$, Wiwik Rismadayanti ${ }^{1}$, \\ Mandike Ginting ${ }^{2}$, Khairani Fitri ${ }^{2}$ \\ ${ }^{1}$ Fakultas Ilmu Keolahragaan Universitas Negeri Medan \\ ${ }^{2}$ Fakultas Farmasi Institut Kesehatan Helvetia \\ Email: rahmanmarpaung@gmail.com
}

\begin{abstract}
Abstrak
Aktifitas fisik maksimal dapat mempengaruhi kesehatan dan performance atlet akibat meningkatnya produksi radikal bebas di dalam tubuh. Tujuan penelitian adalah untuk mengetahui pengaruh aktifitas fisik maksimal terhadap jumlah leukosit dan hitung jenis leukosit pada Atlet Softball Putri Universitas Negeri Medan. Penelitian ini menggunakan metode quasi eksperimen dengan rancangan penelitian one group pretest posttest. Jumlah sampel berjumlah 11 orang. Pengukuran kadar leukosit dan hitung jenis leukosit dilakukan sebelum dan setelah melakukan aktifitas fisik maksimal. Hasil penelitian diperoleh rerata jumlah leukosit pretest 8,37 dan posttest sebesar 13,03; rerata jumlah neutrofil pretest 56,45 dan posttest 46,27; rerata/jumlah limfosit prêtest 33,27 dan posttest 42,90; rerata monosit pretest 6,45 dan posttest 7,63 ; rerata jumlah eusinofil pretest 3,81 dan posttest 3,18 . Hasil uji-t berpasangan menunjukan bahwa aktifitas fisik maksimal dapat meningkatkan jumlah leukosit dan limfosit secara siknifikan sedangkan jumlah monosit meningkat tetapi tidak signifikan. Aktifitas fisik makismal dapat menurunkan hitung jenis neutrofil dan eusinofil, sedangkan hitung jenis basofil tidak ada perubahan. Kesimpulan penelitian adalah aktifitas fisik maksimal dapat mempengaruhi jumlah leukosit dan hitunh $\backslash g$ jenis leukosit.
\end{abstract}

Kata Kunci: Aktifitas fisik maksimal, leukosit, hitung jenis leukosit

\section{A. PENDAhuluan}

Aktifitas fisik merupakan kegiatan yang selalu dilakukan manusia setiap harinya. Aktifitas fisik ini bahkan telah menjadi ciri utama dari manusia. Setiap manusia hampir dipastikan akan melakukan aktifitas fisik setip harinya. Namun, adakalanya manusia belum mampu memilah apa aktifitas fisik yang masih bisa diterima oleh tubuhnya sendiri.

Aktifitas fisik maksimal dapat memicu terjadinya ketidakseimbangan antara produksi radikal bebas dan sistem pertahanan antioksidan tubuh yang dikenal sebagai stres oksidatif (Leeuwnburg dan Heinecke, 2001 dalam Harahap 2008). Selama aktifitas fisik, konsumsi oksigen keseluruh tubuh meningkat sampai 20 kali, sedangkan konsumsi oksigen pada serabut otot diperkirakan meningkat 100 kali lipat. Peningkatan konsumsi oksigen ini berkaitan dilihatnya produksi radikal bebas yang dapat menyebabkan kerusakan sel. Andrian dalam Tortora, dkk (2003) penambahan stres 
oksidatif dapat berakibat terjadinya peningkatan jumlah leokosit melebihi $10.000 \mathrm{sel} /$. Peningkatan hitung jenis leukosit merupakan respon protektif terhadap stres seperti infasi mikroba, aktifitas yang berat, anestesi dan pembedahan.

Manfaat aktifitas fisik bila dilakukan dalam keadaan sehat secara teratur dan menyenangkan, dengan intensitas ringan sampai sedang akan meningkatkan kesehatan dan kebugaran tubuh. Aktifitas aerobik yang demikian akan memperbaiki dan memperlambat proses penurunan fungsi organ tubuh, serta dapat meningkatkan kesehatan dan kebugaran tubuh. Aktifitas aerobik yang demikian akan memperbaiki ketahanan tubuh terhadap infeksi. Aktifitas fisik dengan intensitas maksimal dan melelahkan, dilaporkan justru dapat menyebabkan gangguan imunitas. Atlet yang berlatih dengan intensitas latihan yang maksimal dan melelahkan untuk menghadapi suatu pertandingan, sering tidak dapat melanjutkan ke pertandingan berikutnya karena sakit atau cedera. (Hartanti et al., 1999)

\section{B. METODE PENELITIAN}

\section{Tempat penelitian}

Penelitian ini dilakukan di Stadion Universitas Negeri Medan (UNIMED) Jalan Williem Iskandar Pasar V Medan Estate, Medan untuk kegiatan aktifitas fisik maksimal. Pengukuiran jumlah leukosit dan jumlah jenis leukosit dilakukan di Dinas Kesehatan Provinsi Sumatera Utara UPT Laboratorium Kesehatan Daerah, Jalan Williem Iskandar Pasar V barat No. 4 Medan.

\section{Subjek penelitian}

Subjek penelitian ini berjumlah 11 orang dengan kriteria sebagai berikut:

- sehat dibuktikan dengan hasil pemeriksaan dokter

- mempunyai VO2max yang baik

- tidak mengkonsumsi suplemen antioksidan 2 minggu sebelum dan selama penelitian

- setuju mengikuti pemelitian

\section{Rancangan penelitian}

Jenis penelitian adalah penelitian eksperimental dengan rancangan one group pretest posttest. Pengukuran jumlah leukosit dan hitung jenis dilakukan sebelum dan setelah melakukan aktifitas fisik maksimal dengan cara melakukan Bleep test 


\section{Prosedur Bleep test}

Prosedur pelaksanaan tes bleep adalah sebagai berikut.

Tes bleep dilakukan dengan lari menempuh jarak 20 meter bolak-balik, yang dimulai dengan lari pelan-pelan secara bertahap yang semakin lama semakin cepat hingga atlet tidak mampu mengikuti irama waktu lari, berarti kemampuan maksimalnya pada level bolak-balik tersebut.

1. Waktu setiap level 1 menit.

2. Pada level 1 jarak 20 meter ditempuh dalam waktu 8,6 detik dalam 7 kali bolakbalik.

3. Pada level 2 dan 3 jarak 20 meter ditempuh dalam waktu 7,5 detik dalam 8 kali bolak-balik.

4. Pada level 4 dan 5 jarak 20 meter ditempuh dalam waktu 6,7 detik dalam 9 kali bolak-balik, dan seterusnya.

5. Setiap jarak 20 meter telah ditempuh, dan pada setiap akhir level, akan terdengar tanda bunyi 1 kali.

6. Start dilakukan dengan berdiri, dan kedua kaki di belakang garis start. Dengan abaaba "siap ya", atlet lari sesuai dengan irama menuju garis batas hingga satu kaki melewati garis batas.

7. Bila tanda bunyi belum terdengar, atlet telah melampuai garis batas, tetapi untuk lari balik harus menunggu tanda bunyi. Sebaliknya, bila telah ada tanda bunyi atlet belum sampai pada garis batas, atlet harus mempercepat lari sampai melewati garis batas dan segera kembali lari ke arah sebaliknya.

8. Bila dua kali berurutan atlet tidak mampu mengikuti irama waktu lari berarti kemampuan maksimalnya hanya pada level dan balikan tersebut.

9. Setelah atlet tidak mampu mengikuti irama waktu lari, atlet tidak boleh terus berhenti, tetapi tetap meneruskan lari pelan-pelan selama 3-5 menit untuk cooling down.

\section{HASIL DAN PEMBAHASAN PENELITIAN}

\section{HASIL PENELITIAN}

Berdasarkan hasil analisi data dengan uji Normalitas (Shapiro-Wilk), P>0,05, menunjukan data berdistribusi normal. 
Tabel 1 .

Tabel Hasil Uji Normalitas Data Pengaruh Leukosit dan Hitung Jenis Leukosit Sebelum dan Setelah Aktifitas Fisik Maksimal

\begin{tabular}{|c|c|c|c|c|c|c|}
\hline \multirow{2}{*}{\multicolumn{2}{|c|}{ Variabel }} & \multicolumn{3}{|c|}{ Shapiro-Wilk } & \multirow{2}{*}{$\begin{array}{l}\text { Kriteria } \\
\text { Normal } \\
\end{array}$} & \multirow[t]{2}{*}{ Keterangan } \\
\hline & & Statistic & Df & Sig. & & \\
\hline \multirow[t]{2}{*}{ Leukosit } & Pre test & 0,970 & 11 & 0,884 & & Normal \\
\hline & Post test & 0,951 & 11 & 0,658 & & Normal \\
\hline \multirow[t]{2}{*}{ Neutrofil } & Pre test & 0,945 & 11 & 0,579 & & Normal \\
\hline & Post test & 0,923 & 11 & 0,560 & & Normal \\
\hline \multirow[t]{2}{*}{ Limfosit } & Pre test & 0,937 & 11 & 0,487 & & Normal \\
\hline & Post test & 0,904 & 11 & 0,209 & $p>0,05$ & Normal \\
\hline \multirow[t]{2}{*}{ Monosit } & Pre test & 0,822 & 11 & 0,019 & & T.Normal \\
\hline & Post test & 0,786 & 11 & 0,006 & & T.Normal \\
\hline \multirow[t]{2}{*}{ Eusinofil } & Pre test & 0,863 & 11 & 0,063 & & Normal \\
\hline & Post test & 0,876 & 11 & 0,094 & & Normal \\
\hline \multirow[t]{2}{*}{ Basofil } & Pre test & 0,000 & 11 & 0,000 & & T.Normal \\
\hline & Post test & 0,000 & 11 & 0,000 & & T.Normal \\
\hline
\end{tabular}

Keterangan : $\mathrm{P}>0,05$ : data berdistribusi normal

Berdasarkan hasil pengukuran jumlah leukosit dan hitung jenis leukosit sebelum aktifitas fisik maksimal pada 11 subjek penelitian, didapatkan bahwa nilai rata-rata jumlah leukosit setelah AFM berupa bleep test hingga mencapai denyut nadi maksimal mengalami peningkatan (rata-rata=13,03) dari sebelum AFM (rata-rata=8,37), didapatkan bahwa nilai rata-rata hitung jenis neutrofil setelah AFM berupa bleep test hingga mencapai denyut nadi maksial mengalami penurunan (rata-rata $=46,27, \mathrm{SD}$ $=8,776$ ) dari sebelum AFM (rata-rata $=56,45, \mathrm{SD}=9,55$ ), diketahui bahwa nilai hitung jenis limfosit setelaah melakukakn AFM berupa bleep test hingga mencapai denyut nadi maksimal (rata-rata $=42,90, \mathrm{SD}=7,64$ ) dari sebelum AFM (rata-rata =33,27, $\mathrm{SD}=7,29$ ), diketahui bahwa nilai rata-rata jenis monosit pada pengukuran setelah AFM lebih tinggi (rata-rata=7,63, $\mathrm{SD}=0,67$ ) dari sebelum $\mathrm{AFM}$ (rata-rata=6,45, $\mathrm{SD}=1,29$ ), didapatkan bahwa nilai rata-rata hitung jenis eosinofil setelah AFM berupa bleep test hingga mencapai denyut nadi maksimal mengalami penurunan (rata-rata $=3,18, \mathrm{SD}=2,89$ ) dari sebelum AFM berupa bleep test hingga mencapai denyut nadi maksimal (rata-rata $=3,81, \mathrm{SD}=3,78$ ), dari tabel diatas dapat diketahui bahwa untuk nilai hitung jenis leukosit khususnya basofil, tidak dapat dianalisis karena nilainya $0 \%$ tidak ada perubahan pada saat sebelum dan setelah AFM, seperti tercantum pada tabel 2. 
Tabel 2 .

Kadar Rerata Jumlah Leukosit dan Hitung Jenis Leukosit Sebelum dan Setelah Aktufitas Fisik Maksimal

\begin{tabular}{|c|c|c|c|c|}
\hline No & & abel & Mean \pm SD & Sig (2 tail) \\
\hline \multirow[t]{2}{*}{1.} & \multirow{2}{*}{ Leukosit $\left(10^{9}\right)$} & Pretest & $8,37 \pm 1,57$ & \multirow{2}{*}{0,000} \\
\hline & & Posttest & $13,03 \pm 2,00$ & \\
\hline \multirow[t]{2}{*}{2.} & \multirow{2}{*}{ Neutrofil (\%) } & Pretest & $56,45 \pm 9,55$ & \multirow{2}{*}{0,000} \\
\hline & & Posttest & $46,27 \pm 8,77$ & \\
\hline \multirow[t]{2}{*}{3.} & \multirow{2}{*}{ Limfosit (\%) } & Pretest & $33,27 \pm 7,29$ & \multirow{2}{*}{0,000} \\
\hline & & Posttest & $42,90 \pm 7,64$ & \\
\hline \multirow[t]{2}{*}{4.} & \multirow{2}{*}{ Monosit (\%) } & Pretest & $6,45 \pm 1,29$ & \multirow{2}{*}{0,026} \\
\hline & & Posttest & $7,63 \pm 0,67$ & \\
\hline \multirow[t]{2}{*}{5.} & \multirow{2}{*}{ Eosinofil (\%) } & Pretest & $3,81 \pm 3,78$ & \multirow{2}{*}{0,296} \\
\hline & & Posttest & $3,18 \pm 2,89$ & \\
\hline 6. & Basofil (\%) & Pretest & $0,00 \pm 0,00$ & 1,000 \\
\hline
\end{tabular}

Hasil uji statistik jumlah leukosit, neutrofil, limfosit, monosit diperoleh nilai sgnificancy $\mathrm{p}<0,05$ yang berarti terdapat perbedaan yang signifikan pre test dan post test jumlah leukosit, netrofil limfosit dan monosit setelah aktifitas fisik maksimal. Sementara itu jumlah eusinofil dan basofil tidak berbeda secara statistik

\section{PEMBAHASAN PENELITIAN}

Aktifitas fisik merupakan kegiatan yang selalu dilakukan manusia setiap harinya. Aktifitas fisik ini bahkan telah menjadi ciri utama dari manusia. Setiap manusia hampir dipastikan akan melakukan aktifitas fisik setiap harinya. Namun, adakalanya manusia belum mampu memilah apa aktifitas fisik yang masih bisa diterima oleh tubuhnya sendiri. Manusia kurang pengetahuan tentang aktifitas ini, sehingga tidak mampu membatasi dirinya sendiri.

Aktifitas fisik dapat memicu terjadinya ketidakseimbangan antara produksi radikal bebas dan sistem pertahanan antioksidan tubuh yang dikenal sebagai stres oksidatif (Leeuwnburg dan Heinecke, 2001 dalam Harahap 2008). Selama aktifitas fisik, konsumsi oksigen keseluruh tubuh meningkat sampai 20 kali, sedangkan konsumsi oksigen pada serabut otot diperkirakan meningkat 100 kali lipat. Peningkatan konsumsi oksigen ini berkaitan dilihatnya produksi radikal bebas yang dapat menyebabkan kerusakan sel. Andrian dalam tortora, dkk (2003) penambahan stres oksidatif dapat berakibat terjadinya peningkatan jumlah leokosit melebihi 10.000 sel/ . Peningkatan 
hitung jenis leukosit merupakan respon protektif terhadap stres seperti infasi mikroba, aktifitas yang berat, anestesi dan pembedahan.

Leukosit dapat mendeteksi adanya infeksi yang disebabkan oleh bakteri dan virus, serta dapat melihat kekebalan tubuh serta mendeteksi potensi terjadinya alergi, karena leukosit berperan dalam sistem pertahanan tubuh. Jumlah leukosit perifer dapat menjadi sumber informasi untuk diagnostik dan prognosa serta gambaran adanya kerusakan organ dan pemulihan setelah latihan fisik yang berat. Jumlah leukosit sebanding dengan intensitas kerja dan durasi latihan, tidak bergantung pada jenis kelamin dan tingkat kebugaran subjek. Sodique (2000) dalam (Mukarromah,dkk 2013)

Berdasakan hasil penelitian diketahui rata-rata jumlah leukosit pada saat pre test 8,37 dan mengalami peningkatan pada saat post test setelah aktifitas fisik maksimal sebesar 13,03. Perbedaan jumlah leukosit dari pret test - post test adalah sebesar 4,66. Hasil dari uji-t berpasangan diperoleh nilai significancy $0,000(\mathrm{P}<0,05)$ yang berarti ada perbedaan yang signifikan jumlah leukosit sebelum dan setelah melakukan aktifitas fisik maksimal pada Atlet Softball Putri Universitas Negeri Medan.

Pada beberapa penelitian mengenai pemberian beban maksimal saat pelatihan fisik atau kelelahan yang berat ditemukan adanya perubahan jumlah leukosit pada darah tepi, yang diduga menjadi penyebab meningkatnya kejadian infeksi saluran nafas, karena terjadi penekanan fungsi imunitas, sehingga terjadi penurunan penampilan atlet (Castel, 1993, Ksnig, 2000) dalam (harahap dan pahutar 2017).

Berdasarkan hasil penelitian diketahui rata-rata jumlah neutrofil pada saat pre test 56,45 dan mengalami penurunan pada saat post test setelah aktifitas fisik maksimal sebesar 46,27. Perbedaan jumlah neutrofil dari pre test-post tesadalah 10,18. Hasil uji t berpasangan diperoleh nilai jenis neutrofil significancy $0,000(\mathrm{P}<0,05)$ yang berarti bahwa terdapat perbedaan yang signifikan hitung jenis neutrofil sebelum dan setelah aktifitas fisik maksimal pada Atlet Softball Putri Universitas Negeri Medan.

Penelitian sesuai dengan Harahap (2008) yang menyatakan bahwa penurunan kadar neutrofil dikarenakan oleh latihan fisik maksimal yang menyebabkan inflamasi sehingga berdiapesis ke dalam jaringan meninggalkan ruang pembuluh darah.

Berdasarkan hasil penelitian diketahui rata-rata jumlah limfosit pada saat pre test 33,27 dan mengalami peningkatan pada saat post test setelah aktifitas fisik maksimal sebesar 42,90. Perbedaan jumlah neutrofil dari pre test - post tesadalah 9,63. Hasil uji t 
berpasangan diperoleh nilai jenis limfosit significancy $0,000(\mathrm{P}<0,05)$ yang berarti terdapat perbedaan yang signifikan terhadap hitung jenis limfosit sebelum dan setelah aktifitas fisik maksimal pada Atlet Softball Putri Universitas Negeri Medan.

Penelitian yang dilakukan oleh Harahap (2008), yang menyatakan bahwa limfosit meningkat setelah aktifitas fisik maksimal dikarenakan oleh aktifitas limfosit yang menghasilkan pertahanan imun dan latihan memicu limfosit keluar dari line menuju aliran darah karena rangsangan dari hormon kortisol.

Berdasarkan hasil penelitian diketahui rata-rata jumlah monosit pada saat pre test 6,45 dan mengalami peningkatan pada saat post test setelah aktifitas fisik maksimal sebesar 7,63. Perbedaan jumlah monosit dari pre test-post tesadalah 1,18. Hasil dari uji wilcoxon diperoleh nilai significancy $0,26(\mathrm{P}<0.05)$ yang berarti terdapat perbedaan yang signifikan tidak bermakna jumlah monosit sebelum/dan setelah aktifitas fisik maksimalpada Atlet Softball Putri Universitas Negeri Medan

Berdasarkan hasil penelitian diketahui rata-rata jumlah eusinofil pada saat pre test 3,81 dan mengalami penurunan pada saat post test setelah aktifitas fisik maksimal sebesar 3,18. Perbedaan jumlah neutrofil dari pre test - post tesadalah 0,63. Hasil uji $\mathrm{t}$ berpasangan diperoleh nilai jenis neutrofil significancy $0,296(\mathrm{P}>0,05)$ yang berarti tidak terdapat perbedaan yang signifikan terhadap hitung jenis eusinofil sebelum dan setelah aktifitas fisik maksimal pada Atlet Softball Putri Universitas Negeri Medan.

Dilaporkan pada penelitian lain bahwa terjadi penurunan eusinofil akibat diberikan latihan yang berat. Hal ini disebabkan adanya stres akibat aktifitas atau latihan mengakibatkan terjadinya peningkatan sekresi hormon dan korteks adrenal dan salah satu produksi yang dihasilkan oleh hormon ini mengakibatkan penurunan jumlah eusinofil dalam darah atau eosinopenia walaupun hal ini masih kontrakdiktif karena ada pendapat lain yang menyatakan terjadinya eosipenia relatif berhubungan dengan adanya marked limfositosis. Sama halnya dengan penelitian Harhap (2008) yang menyatakan bahwa penurunan kadar eusinofil dikarenakan latihan fisik yang menyebabkan stes sehingga meningkatkan sekresi hormon dan salah satu produksi dari hormon tersebut mengakibatkan penurunan jumlah eusinofil.

Berdasarkan hasil penelitian diketahui rata-rata jumlah basofil pada saat pre test 0 dan pada saat post test 0 , karena tidak ada perubahan pada saat sebelum dan setelah aktifitas fisik maksimal sehingga variabel tersebut tidak dilakukan uji statistik. 
Hasil penelitian ini sejalan dengan penelitian yang dilakukan Harahap (2008) yang menelitian tentang "Pengaruh Aktifitas Fisik Maksimal Terhadap Jumlah Leukosit dan Hitung Jenis Leukosit pada Mencit Jantan”. Dengan kesimpulan didapat bahwa aktifitas fisik maskimal berpengaruh terhadap peningkatan leukosit, limfosit secara signifikan dan aktifitas fisik maksimal juga berpengaruh terhadap penurunan hitung jenis neutrofil, eusinofil, monosit secara signifikan, namun aktifitas fisik maksimal tidak berpengaruh terhadap perubahan hitung jenis basofil.

\section{KESIMPULAN}

Dari pengujian hipotesis dan pembahasan penelitian, maka dapat ditarik kesimpulan sebagai berikut:

1. Aktifitas fisik maksimal meningkatkan jumlah leukosit secara bermakna.

2. Aktifitas fisik maksimal menurunkan jumlah jenis neutrofil secara bermakna.

3. Aktifitas fisk maksimal meningkatkan jumlah jenis limfosit secara bermakna.

4. Aktifitas fisik maksimal meningkatkan jûmlah jenis monosit namun tidak bermakna.

5. Aktifitas fisik maksimal menurunkan jumlah jenis eusinofil namun tidak bermakna.

6. Aktifitas fisik maksimal tidak berpengaruh terhadap perubahan jumlah hitung jenis basofil.

\section{Daftar Pustaka}

Arikunto, Suharsimi. (2006). Prosedur Penelitian. Jakarta. Rineka Cipta.

Harahap, N.S. (2008). Pengaruh Aktifitas Fisik Maksimal Terhadap Jumlah Leukosit dan Hitung Jenis Leukosit Pada Mencit (Mus Musculus L) Jantan. USU erepository. Medan.

Harahap, N.S., dan Sipahutar, U.P. (2017). Pengaruh Aktifitas Fisik Aerobik dan Anaerobik Terhadap Jumlah Leukosit Pada Mahasiswa Ilmu Keolahragaan Universitas Negeri Medan.Sains Olahraga : Jurnal Ilmiah Ilmu Keolahragaan. Medan. Vol. 1. No. 2. Hal 33-41.

Harsono.(1988). Coaching dan Aspek-Aspek Psikologi dalam Coaching. Jakarta. Lembaga Pendidikan Tenaga Pendidikan.

Hartanti, M. (1999). Kadar Imunoglobulin A dalam Air Liur Atlet Pasca Pertandingan. Majalah Kedokteran Indonesia. 22. Ed. 
Irianti, E., dan Ardinata, D. (2008). Pengaruh Aktifitas Fisik Sedang Terhadap Hitung Leukosit dan Hitung Jenis Sel Leukosit Pada Orang Tidak Terlatih.Majalah Kedokteran Nusantara. 41 (1).

Laeto,A.B. (2015). Respon Akut Jumlah Leukosit dan Hitung Jenis Leukosit Pada Kelompok Pemain Futsal Malam dan Pagi di Kota Makassar.Universitas Hasanuddin. Makassar.

L, Sherwood. (1996). Fisiologi Manusia dari Sel ke Sistem. Jakarta. EGC.

Lianiwati, V. (2011). Pembaerian Ekstrak Buah Naga Merah Menurunkan Kadar F2 Isoprostan Pada Tikus Putih Jantan yang diberi Aktifitas Berlebih. Universitas Udayana. Denpasar Bali.

Mukarromah, S.dkk. (2013). Pengaruh Latihan Aquarobik Terhadap Jumlah Hitung Jenis Leukosit Pada Wanita Obesitas di Kota Semarang.Jurnal Media Ilmu Keolahragaan Indonesia. Volume 3. Edisi 1 Juli 2013. ISSN: 2088-6802.

Sharkey, B.J. (2003). Kebugaran dan Kesehatan. Jakarta. P.T. Raja Grafindo Persada.

Sinaga, F.A., dan Harefa, R. (2017). Pengaruh Aktifitas Fisik Maksimal Terhadap Jumlah Leukosit Pada Mahasiswa Jurusan Ilmu Keolahraggaan. GenerasiKampus. Medan. Hal 1-7.

Sudjana. (2002). Metode Statistika. Bandung. Tarsito

Syaifuddin. (2009). Hubungan Jumlah Leukosit Total Dengan Aterosklerosis Arteri Karotis Interna Pada Pasien Paska Stroke Iskemia. Universitas Dipenogoro. Semarang.

Underwood, J.C.E. (1999).Patologi Umum dan Sistematik (General AndSystematic Pathology) Alih Bahasa. Sarjadi (Volume 2, Edisi 2). Jakarta. Penertbit Buku Kedokteran EGC 